Bożena Kucała

10.15290/cr.2016.14.3.01

Jagiellonian University, Kraków

\title{
Houses as sites of memory in Penelope Lively's writings
}

\begin{abstract}
This paper will analyse the representation of houses in selected novels and non-fiction by Penelope Lively. Houses feature in her writings as material objects as well as immaterial forms created by the human psyche; they may also be conceptualised as organic beings whose lives mirror the lives of their inhabitants. However, it will be argued that for the characters in Lively's novels houses function primarily as sites of memory. Houses are treated as repositories of the past, both because they hold secure its material remnants and because they have the potential to evoke memories and thus enable people to forge and maintain meaningful connections with the past. The article will also take account of Lively's three autobiographical books, Oleander, Jacaranda: A Childhood Perceived, A House Unlocked, and Ammonites and Leaping Fish, in which the writer embarks on the project of retrieving memories by exploring, respectively, three houses she used to reside in as "material memoirs" of her own past as well as collective history.
\end{abstract}

Keywords: Penelope Lively, memory, autobiography, the house in fiction, sites of memory.

In their essay on representations of the house in literature and culture, Janet Larson, Francesca Saggini and Anna-Enrichetta Soccio emphasise the inescapable duality inherent in this type of dwelling. On the one hand, it is a material object, a "thing made of bricks and mortar, poured concrete, cinder block, fieldstone, fitted logs or baked mud." Owing to its substantiality, the house secures the inside against the outside, separates the private space from the public space, and offers its inhabitants "a sense of stability against the ravages of time." On the other hand, the space enclosed by the walls of the house also becomes a mental construct, endowed with subjective, personal connotations (1-2). In Poetics of Space Gaston Bachelard conceptualised the house as a form created by the human psyche rather than a mere architectural structure: "A house that has been experienced is not an inert box. Inhabited space transcends geometrical space" (47). Bachelard claims that the human being "experiences the house in its reality and in its virtuality, by means of thought and dreams" (5). In its latter function - which is the real subject of Bachelard's analysis - the house gives a shape to human life by integrating "thoughts, memories and dreams" (6-7).

This duality of the house as both a material object and a mental construct tends to underlie representations of houses in Penelope Lively's novels and memoirs. Indeed, the opening of one of her latest novels, Family Album (2009), revolves around a contrast between these two dimensions. Split into several voices and perspectives, the novel achieves a degree of unity thanks to its setting. 
As Lorna Bradbury observes in her review, "the house in Family Album has as strong a presence as any of the characters" (Bradbury). Allersmead is the background to the lives of several characters, whose identity may be defined with regard to their physical and mental distance from it. The first episode depicts one of the middle-aged daughters arriving at Allersmead for a family reunion. Whereas her partner sees a mere building, for Gina the sight of the house triggers a powerful influx of memories:

Gina turned the car off the road and into the driveway of Allersmead. At this point she seemed to see her entire life flash by....

Philip, in the passenger seat, saw a substantial Edwardian house, a wide flight of steps up to a front door with stained-glass panels, a weedy sweep of gravel in front. (1)

In a house which has transcended its materiality, objects become reminders of human experiences. In the house depicted in Family Album, each room is "branded" and "vibrant with references" to family rituals (15-16). As one of the characters says of Allersmead, "This is a real family house and it's got all the scars" (13).

Indeed, the house in Lively's writings is not by definition the Bachelardian "space we love" (Bachelard, xxxv). Lively does not idealise houses in her fiction - nor is she prepared to overlook the downsides of her own family life in her memoirs (Oleander, Jacaranda, 1994). ${ }^{1}$ The walls enclosing the inhabited space may function as a shelter or, conversely, as a trap; the separation of the house from the outside world may lead to alienation; the stability connoted by the house may degenerate into stagnation.

\section{The house as a space in time}

Whatever houses connote to their inhabitants in Lively's fiction or to herself in her autobiographical writings, Lively repeatedly asserts that if "the geometrical space" of a house is transcended as a result of human experience, it is a process which takes place over a period of time. Houses acquire their identity when layers of experience accumulate within their walls; in Lively's books family dwellings are silent but material witnesses to the progress of individual lives, the succession of generations, and even the march of history. As a fusion of space and time, the houses in her books become manifestations of the Bakhtinian chronotope, in which "spatial and temporal indicators are fused into one carefully thought-out, concrete whole. Time, as it were, thickens, takes on flesh, becomes artistically visible; likewise, space becomes charged and responsive to the movements of time, plot and history" (Bakhtin, 84).

\footnotetext{
1 There is much overlap between Lively's novels and the ideas expressed in her non-fiction. Kerstin Ebel notes that while reading the autobiographical books Oleander, Jacaranda and A House Unlocked, "it becomes clear how many of her own memories and experiences and how much of her knowledge of places Lively has used in her fiction - whether consciously or subconsciously" (2). This observation also pertains to her latest autobiographical book, Ammonites and Leaping Fish.
} 
The intersection of space and time as the defining quality of the house is exemplified in Lively's account of Bulaq Dakhrur, the house of her childhood in the vicinity of Cairo. Lively was born and spent the first twelve years of her life in the British community in Egypt. Forty years later, she made a return visit to the place. The account of the visit, interspersed with memories of her childhood, is the subject of her first autobiographical book Oleander, Jacaranda. The prime destination of the journey is the former family house, but the visit to Egypt also makes her feel like a time traveller (5). After finding the house she is able to indulge in a remembrance of things past. Lively discovers that the building has been converted to a school and that all the former surroundings are gone; therefore, the house becomes all the more precious to her as the sole remainder of the past: "Nothing left but the house, stolidly clinging on. Somehow, this was not sad but curiously exhilarating. I had not expected it to be there at all. And now the building seemed in some odd way to have the dignity of the Sphinx, which looks aloofly out over the degradation all around" (7). But the visitor sees more than the physical building in its present shape - she is aware of its previous existence, inextricably intertwined with her childhood: "And there was also the powerful feeling that on some other plane of existence the Ur-house was still there also, with the eucalyptus avenue and the lawns and the flower beds, and I with it, a ghost-child for ever riding my bike up and down the drive..." (8). Her memories are suffused with nostalgia; the place connects her with her younger self, it offers her security and reassurance (9). The encounter with Bulaq Dakhrur, her personal chronotope, releases such vivid recollections that she is mentally transported back to her childhood and narrates her memories in the present tense. Lively records her astonishment at the clarity of her memories and notes that the moments engraved on her mind are "almost all focused on the house, or the garden" (29). The place becomes the starting point of her journey into the past. In her imagination, Lively recreates in great detail the interior of the house as it was in her early years, methodically moving from room to room and commenting on what the sights connote. One piece of furniture in particular commands her respect as a palpable link between past and present: the old tallboy which now stands in her bedroom in London still furnishes the hall of her imaginary Egyptian house (32).

\section{Housing memories}

The capacity to read the references encoded in the space of the house originates in memory. It is human memory which endows houses with an identity and confers upon them the status of being eloquent evidence of the past. Both in her fiction and her non-fiction, Lively never tires of stressing the importance of the past in constituting individual and collective identity. In her other autobiographical narrative, Ammonites and Leaping Fish (2013), she asserts that "The mind needs its tether in time, it must know where it is - in the perpetual slide of the present, with the ballast of what has been and the hazard of what is to come" (123). In an interview for Publishers Weekly the writer declared:

I am extraordinarily interested in history ... worried about how a lot of people don't realize that history

is true, that it has actually happened... Perhaps what I am interested in even more is the operation of 
memory in every possible sense, the way in which both people and landscape ${ }^{2}$ are composed of memory, the ways in which the physical world is composed of memory. (quoted in Blom, 240) ${ }^{3}$

In Lively's writings, houses, in their virtual dimensions, are also composed of memory, both personal and collective.

In his essay "Between Memory and History: Les Lieux de Mémoire" Pierre Nora argues that "Memory takes root in the concrete, in spaces, gestures, images, and objects" (9); memory is anchored, "crystallizes and secretes itself" in "sites of memory" (lieux de mémoire) (7). Following Maurice Halbwachs, Nora contends that since in the modern post-industrial world we can no longer rely on spontaneous collective memory, we must intentionally create repositories of the past: "Museums, archives, cemeteries, festivals, anniversaries, treaties, depositions, monuments, sanctuaries, fraternal orders - these are the boundary stones of another age, illusions of eternity" (12). The concept of the house as a site of private, and occasionally also collective memory, underlies Lively's depiction of family dwellings in her novels and autobiographical books. The buildings and the objects they contain testify to the reality of the past and provide the grounding for re-imagining it. However, Lively does not share Nora's account of the genesis of lieux de mémoire. The house is not deliberately created to anchor memories; instead, it naturally acquires this function in the course of human habitation.

In Poetics of Space Bachelard stresses the role of the house in retaining memories: "thanks to the house, a great many of our memories are housed, and if the house is a bit elaborate, if it has a cellar and a garret, nooks and corridors, our memories have refuges that are all the more clearly delineated" (8). John Locke once defined memory as "the storehouse of our ideas" (193). The metaphor of storing or housing is particularly apt in describing the way Lively conceptualises the house. The writer reiterates her belief that the past leaves its deposits like layers of archaeological artefacts; landscapes, buildings and people are palimpsests ("We are all of us palimpsests; we carry the past around" [Lively 2014, 174]; "we are each of us the accretion of all that we have been" [ibid. 57]). But "storing" may be understood quite literally, too. The houses of man, Bachelard says, are also "the houses of things" (xxxvii). In describing the house in which she now lives, Lively states: "My house has many things, too, besides those books - the accretion of a lifetime" (Lively 2014, 199). As is shown in the opening scene in Family Album, quoted at the beginning of this article, houses become storehouses of the past but only those who perceive a particular building as a site of memory can activate the house's potential to display "the shining threads of reference" (cf. Lively 2001, xi). In the last chapter of Ammonites and Leaping Fish Lively chooses to discuss six objects stored in

2 Lively is also the author of the book The Presence of the Past: An Introduction to Landscape History (1976).

3 Cf. the passage in Lively's novel The Road to Lichfield (1977) in which the protagonist reflects on the landscape while driving to Lichfield: "the landscape itself [seemed like] a palimpsest, suggesting another time, another place. Edgehill recalled the Civil War; Tamworth, lurking over to the right, had something Saxon about it, she seemed to remember. Her own past, too, waved a cheery hand from over the horizon, or the other side of the motorway interchange.... Private and public memory, it seemed, were fused on the R.A.C. Route Guide” (1). 
her house because they "articulate something of who [she is]" (199). Since they embody references to the past, the objects constitute "a sort of material memoir" (200). ${ }^{4}$ Arguing that domestic spaces play a crucial part in (auto)biographies, Kathy Mezei writes: "Interior domestic spaces (furniture, rooms, doors, windows, stairs, drawers - familiar, everyday objects) which have and could be perceived as banal and ordinary, and hence insignificant, are vital to the shaping of our memories, our imagination, and our 'selves'” (82).

Whereas in Oleander, Jacaranda Lively's recreation of the past is backed up by a mental tour of her imaginary Ur-house, in a later autobiographical book, A House Unlocked (2001), she employs a similar mnemonic technique, but in a self-conscious, systematic manner. The house in question is Golsoncott, an Edwardian country house in Somerset, which likewise has personal reverberations for the writer. She remembers it as the home of her maternal grandmother, in which she often stayed after her arrival from Egypt. Following the mode of presentation of her Egyptian house in Oleander, Jacaranda, Lively in this instance extends her range of reference, moving away from strictly personal experience towards family history and even further, towards public history. The writer's professed aim is to give the immediate and the particular a universal resonance (ix). Cressida Connolly describes the book as "a curious and mostly engaging hybrid in which events of the twentieth century are extrapolated from objects in the house" (Connolly).

Lively reiterates her perception that houses constitute embodiments of the past; their interiors and the objects contained in them are tangible relics of what has been. On the other hand, the materiality of things evokes a whole range of mental images from the past. Lively articulates her beliefs very clearly in the Preface to A House Unlocked, in which she expounds on her plan to use the house and the objects in it as memory prompts:

the entire place - its furnishings, its functions - seemed like a set of coded allusions to a complex sequence of social change and historical clamour. Objects had proved more tenacious than people - the photograph albums, the baffling contents of the silver cupboard, the children on my grandmother's sampler of the house - but from each object there spun a shining thread of reference, if you knew how to follow it. (xi)

The house she remembers does not exist anymore, but Lively's memories of it remain so vibrant that she makes a virtual tour of Golsoncott the structural principle of her book: "In my head, I can still move easily and vividly around it. The furnishings are precise and clear, the sounds and smells are as they ever were. I can walk through the front door into the vestibule, and thence into the hall" (ix).

\footnotetext{
4 In the novel The Road to Lichfield, the heroine recalls her past as she sorts out her late father's house (which used to be her own family house): "In the spare bedroom, where she would sleep, her own past proffered itself in concrete form: a row of her old books on the mantelpiece, a spurned wedding-present vase on the windowsill, a pair of her shoes in the wardrobe" (12).
} 
In his overview of modern theories of memory, Michael Rossington observes that Nora's concept of lieux de mèmoire "is indebted explicitly to the exploration of the significance of loci memoriae, or 'memory places' in medieval thought in Yates' The Art of Memory" (136). Frances A. Yates's well-known study of memory-training techniques from ancient Greece until early modernity, first published in 1966, stressed the crucial importance of memory systems in the pre-print age. The ancient and medieval art of memory used architecture as memory places. According to Yates, Quintilian's Institutio oratoria offers the best description of the process of memorisation and recollection (18). The first step recommended in this and other ancient guides is to impress on the memory a place, preferably a spacious building; subsequently, the ideas to be remembered are to be placed in the imagination in chosen locations within the building. In order to retrieve these memories, one must revisit the space in one's imagination.

The influence of Yates's book is acknowledged by Lively in the Preface to A House Unlocked. By her own admission, Yates's detailed discussion of memory as an art provided her with a methodology for retrieving her own memories:

Frances Yates's fine book ... describes the system whereby the sequence of an oratorical argument was retained by means of the creation of an imaginary mansion, within which the orator moved from room to room, each space serving as a stage in the argument, and the emotive trappings - a statue, an urn, a painting - acting as prompts for specific flights of language.

In the same way, I can move around my memory house and focus upon different objects. The house itself becomes a prompt - a system of reference, as assemblage of coded signs. (x)

The description of the dining room ("The Knife Rests, the Grape Scissors and the Bon-Bon Dish") is an excellent illustration of Lively's method. The room and its objects seem infinitely familiar - with their arrangement, colours, smells and their minor defects. The writer appears to be reincarnated as her younger self: "There is a sense in which I am still there, a lumpen teenager gripped by the roller-coaster emotions of that turbulent period of life" (200). ${ }^{5}$

Thus, adhering to metaphors of space, it may be said that the house in both its physical and imagined form offers a genuine passage back to the living past.

\section{The house as a living space}

Whereas in Bachelard's poetics the house operates on the principle of the "psychological integration" of individuals (Bachelard, xxxvi), for Lively the house integrates individual life with history. Kathy Mezei contends that domestic spaces connote far more than the immediate context for ar-

\footnotetext{
5 Ch. 3 of Poetics of Space is devoted to the psychological implications of drawers, chests and wardrobes. They may be places for hiding secrets and mysteries, dreams and memories. The casket, for example, in Bachelard's formulation, "contains the things that are unforgettable, unforgettable for us, but also unforgettable for those to whom we are going to give our treasures. Here the past, the present and a future are condensed. Thus the casket is memory of what is immemorial" (84).
} 
ticulating the self: "Narrating the home ... offers a convenient and familiar medium for investigating self and subjectivity by means of the intersection of space and time through memory and the histories and generations of the house's inhabitants and of space" (83). A House Unlocked is "elegiac yet resolutely unsentimental" (Kakutani) as the significance of the building is shown to exceed Lively's personal recollections and even familial memories. The dining room at Golsoncott connotes the family rituals which took place in it but, in a broader context, is also emblematic of the period of country houses, now gone. The objects, having lost their original function, "provide the fringe furnishing of a significant narrative" (Lively 2001, 197). The narrative which the writer spins out of her recollections concerns social change in post-war England - the erosion of social hierarchies, the disappearance of domestic service, the dispossession of the landowning classes and the erosion of the "rock-solid [social] confidence" typified by her grandmother (200). The refashioning of the lifestyle of Golsoncott's owners was a consequence of the deprivations incurred by the Second World War. Their house reflected the change by contracting its habitable space accordingly: "The place adjusted, as buildings do" (208). In the words of Mezei, "because domestic spaces are the product of a society, they express and reinforce its norms, social practices and ideologies" (81); this also means that as social practices evolve, domestic spaces are subject to change and readjustment.

The houses Lively creates in her fiction have the same capacity to respond to the lives that are lived in them. In her novel Passing On (1989) the writer draws parallels between the condition of the house and the lives of the middle-aged brother and sister who continue to inhabit it, out of inertia rather than genuine attachment. Greystones is marked by the oppressive personality of their mother; the house is in a state of decay and disrepair, which corresponds to the unfulfilled and dreary existence of Helen and Edward Glover. Helen's half-hearted efforts at renovating the house are correlated with her unsuccessful and belated attempts at changing her life. Greystones used to be her late mother's exclusive territory. Now, as Helen slowly begins to shake off her mother's overpowering influence, the house appears to assist her in the process:

[The mother's] presence was still loud and strong, but patchily so; there were occasional moments when she was not there at all, when it was possible to walk up the stairs or into the kitchen without expecting to see her. The black holes were becoming grey; Helen could see the substance of the house behind them, as though brick, stone and wood were extinguishing her mother. (46)

In Family Album, after a family secret has been revealed, the house "seems to swing a little, and reassemble itself differently" (198). At night, when its inhabitants go to sleep, Allersmead subsides to rest as well (8).

Indeed, houses seem to be vicariously animated by human presence. Allersmead is represented as an organic structure with its own life span. It "rose from the mud of a late Victorian building site," "has experienced" about 43,000 days since then, "has known over a century of breakfasts," "has weathered" the disappearance of domestic service and the arrival of modern household ap- 
pliances, "has seen birth and death and a great deal of sex," "has accommodated itself to new habits and practices" (29-30). Allersmead is an example of a house which, as Bachelard said, "starts to live humanly" (48). In a parallel with the break-up of the family, the house begins to disintegrate and is eventually put up for sale.

While it lives, Allersmead stores memories, becoming a "silent witness": the house "hears everything" and "knows all that has been said, all that has been done" (77). The identity of a family house may "transcend geometrical space" to such an extent that the physical dimension of the building becomes inessential. The house may change its mode of being to a "mansion in the mind" (Lively 2001, ix), constructed out of people's memories. From Lively's perspective, her grandmother's house has undergone this particular process, as the writer explains in the Preface to A House Unlocked. Such an experience is shared by Gina, the main character in Family Album. As she revisits Allersmead to prepare it for its sale, memories and associations flood it, obscuring the actual building:

... the smells take her to a more intimate Allersmead, to the Allersmead-in-the-head, to a raft of private moments that come swimming up from the long darkness of the years, the strange assortment of glimpses that are known as memory. All of these are tacked to Allersmead; in all of them Allersmead is the backdrop ... . (256)

Thus, the house in Lively's writings may become a site of memory in a double sense: a physical location evocative of the past, or a construct erected within the space of memory.

\section{Conclusion: "the open shelf"}

The representation of the house in Family Album echoes Lively's observation made in A House Unlocked that "Every house tells a story" (220). In both her fiction and her autobiographies the writer insists on the public aspect of these stories, in addition to their obvious personal significance. Joanna Briscoe comments that Family Album reads like "an anthropological study of the English middle classes from the 1970s to the present" (Briscoe). Lively's portrayal of her grandmother's Edwardian mansion in A House Unlocked is driven by a similar intention to make the particular emblematic of historical processes: "the house becomes a secret mirror of the times, arbitrary and selective, reflecting shafts of light from unexpected directions" (Lively 2001, 220). The writer recalls the house again in Ammonites and Leaping Fish, stressing her expanding perspective - the house and its contents have become "signifiers for the century" (109).

In all her writing, Lively repeatedly asserts the interconnectedness of private and public pasts. In the chapter on memory included in Ammonites and Leaping Fish she distinguishes between individual and collective memory, comparing the former to "our own locked cupboard" and the latter to "the open shelf available for all" (136). In accordance with these domestic metaphors, it might be said that what the writer tries to do, especially in her autobiographical books, is to unlock the cupboard and transfer its contents to the open shelf. In this way, a site of personal memory may be mapped onto the larger territory of the collective past. 


\section{References:}

Bachelard, Gaston. 1994. The Poetics of Space. Trans. Maria Jolas. Boston: Beacon Press.

Bakhtin, M. M. 1990. "Forms of Time and of the Chronotope in the Novel: Notes toward a Historical Poetics.” The Dialogic Imagination: Four Essays. Trans. Caryl Emerson and Michael Holquist. Ed. Michael Holquist. Austin: University of Texas Press, 84-258.

Blom, Frans. 1997. "The Novels of Penelope Lively." New Developments in English and American Studies: Continuity and Change. Proceedings of the Seventh International Conference on English and American Literature and Language. Kraków, March 27-29, 1996. Ed. Zygmunt Mazur and Teresa Bela. Kraków: Universitas, 237-48.

Bradbury, Lorna. 2009. "Family Album by Penelope Lively: Review." The Telegraph 1 August 2009. 30 July 2016. www.telegraph.co.uk/culture/books/bookreviews/5949326/Family-Album-byPenelope-Lively-review.html

Briscoe, Joanna. 2009. "Family Album by Penelope Lively." The Guardian 8 August 2009. 30 July 2016, www.theguardian.com/books/2009/aug/08/family-album-penelope-lively-review

Connolly, Cressida. 2001. "So Many Rooms - But No Room for Sentiment: A House Unlocked, Penelope Lively." The Observer 26 August 2001. 30 July 2016, www.theguardian.com/books/2001/ aug/26/biography.features1

Ebel, Kerstin. 2004.“... Something that People Can't Do Without”: The Concepts of Memory and the Past in the Work of Penelope Lively and Other Contemporary British Writers. Heidelberg: Universitätsverlag Winter.

Kakutani, Michiko. 2002. "Finding Memories in an Ancestral Home. A House Unlocked by Penelope Lively." The New York Times: Books 17 May 2002. 25 July 2016, www.nytimes. com/2002/05/17/books/books-of-the-times-finding-memories-in-an-ancestral-home.html

Larson, Janet, Francesca Saggini and Anna-Enrichetta Soccio. 2012. "Housing Fictions in Time: An Introduction." European Journal of English Studies 16.1, 1-8.

Lively, Penelope. 1983. The Road to Lichfield. Harmondsworth: Penguin.

Lively, Penelope. 1990. Passing On. London: Penguin Books.

Lively, Penelope. 1995 [1994]. Oleander, Jacaranda: A Childhood Perceived. London: Penguin Books.

Lively, Penelope. 2001. A House Unlocked. London: Viking.

Lively, Penelope. 2009. Family Album. London: Penguin Books.

Lively, Penelope. 2014 [2013]. Ammonites and Leaping Fish: A Life in Time. London: Penguin Books.

Locke, John. 1894. An Essay Concerning Human Understanding. Vol. 1. Collated and annot., with prolegomena, biogr., crit., and historical by Alexander Campbell Fraser. Oxford: Clarendon Press.

Mezei, Kathy. 2005. "Domestic Space and the Idea of Home in Auto/Biographical Practices." Tracing the Autobiographical. Ed. Marlene Kadar, Linda Warley, Jeanne Perreault and Susanna Egan. Waterloo, ON: Wilfrid Laurier University Press, 81-95. 
Nora, Pierre. 1989. "Between Memory and History: Les Lieux de Memoire." Trans. Marc Rodebush. Representations 26. Special Issue: Memory and Counter-Memory, 7-24.

Rossington, Michael. 2007. "Introduction: Collective Memory." Theories of Memory. A Reader. Ed. Michael Rossington and Anne Whitehead. Edinburgh: Edinburgh University Press, 134-138.

Rossington, Michael and Anne Whitehead, eds. 2007. Theories of Memory. A Reader. Edinburgh: Edinburgh University Press.

Yates, Frances A. 1999 [1966]. The Art of Memory. London: Pimlico. 